\title{
PAUL MATTICK 1904-1981
}

Meddelelsen om Paul Matticks død nåede os først efter at dette nummer af Kurasje var gået til sætning. Det var ikke praktisk muligt at producere en artikel, der beskrev Paul Matticks betydning for den danske marxistiske venstrefløj. Imidlertid $\emptyset$ nsker vi her foreløbig at benytte denne sørgelig lejlighed til at understrege betydningen af den påvirkning og inspiration, der politisk, teoretisk og menneskeligt er udgået fra Paul Mattick og som for mange af os har været af helt afgørende karakter.

Vi har derfor valgt at bringe en kort artikel, hvor Mattick selv resumerer nogle hovedproblemstillinger, som han og hans kreds arbejdede med under den store depression i 1930erne. Hermed opnår vi flere ting samtidigt.

Vi forbliver i overensstemmelse med Paul Mattick selv, når vi ikke isolerer hans indsats fra de grupper og bevægelser, han var en aktiv del af. Han modsatte sig ethvert forsøg på at gøre noget særligt ud af hans person, idet han mente: »Mine ideer og holdninger er ikke personlige kvaliteter, men resultatet af omstændigheder jeg har delt med mange mennesker.«

Vi henleder desuden opmærksomheden på en række problemstillinger og analyser af disse, som den aktuelle internationale kapitalistiske krise har reaktualiseret. Disse analyser har langt større relevans og fortjener større opmærksomhed end de hidtil er blevet tildelt. Her diskuteres en socialistisk bevægelses mål og problemer med eksemplarisk radikalitet og intensitet. Her formidles erfaringer fra klassekampe i en historisk situation, der må have meget at sige os lige nu.

Artiklen har Paul Mattick skrevet i 1969 i anledning af et genoptryk af de tidsskrifter fra 30erne for hvilke han var hovedansvarlig. (»New Essays 1934-43«, vol. 1-6, Greenwood Reprint, Connecticut 1970). 